\title{
Maxillary Sinus Cancer pMO TNM Finding
}

National Cancer Institute

\section{Source}

National Cancer Institute. Maxillary Sinus Cancer pMO TNM Finding. NCI Thesaurus. Code C65022.

Maxillary sinus cancer with no distant metastasis. (from AJCC 6th Ed.) 